\title{
Conversion of native rangelands into cultivated pasturelands in subtropical ecosystems: Impacts on aggregate- associated carbon and nitrogen
}

\author{
S. Xu, M.L. Silveira, L.E. Sollenberger, P. Viegas, J.J.J. Lacerda, and M.V. Azenha
}

\begin{abstract}
Soil organic carbon (SOC) plays a critical role in the sustainability of grazingland ecosystems around the world. However, maintaining or increasing SOC levels remains a major challenge, particularly in subtropical regions where coarse-textured soils predominate. This study evaluated the long-term (>20 years) impacts of grazingland intensification (conversion of native rangelands into more intensively managed silvopasture and sown pasture) on SOC and nitrogen $(\mathrm{N})$ responses in particle size/density fractions. Treatments consisted of field replicated $(n=2)$ experimental sites that represented a gradient of intensification ranging from native rangelands (low intensification), pine (Pinus spp.)-bahiagrass (Paspalum notatum) silvopasture (moderate intensification), and bahiagrass pastures (high intensification). Soil organic $\mathrm{C}$ and $\mathrm{N}$ increased in response to the conversion of native rangelands into more intensively managed grazinglands, but no difference was observed in total SOC and $\mathrm{N}$ between silvopasture and sown pasture. Despite the positive impact of intensification on SOC and $\mathrm{N}$ pools, accumulation occurred primarily in more labile fractions. For instance, at the 0 to $10 \mathrm{~cm}$ depth, light-free $\mathrm{C}$ (LF-C) increased from $12.9 \mathrm{~g} \mathrm{~kg}^{-1}$ soil in the native rangeland to $24.7 \mathrm{~g} \mathrm{~kg}^{-1}$ soil in the sown pasture. Largest differences between the ecosystems were observed at the 10 to $20 \mathrm{~cm}$ depth where LF-C increased by as much as $170 \%$ following the conversion from native rangelands to sown pasture. Similar responses were also observed for $\mathrm{N}$. Grazingland intensification showed no effect on soil aggregation, but SOC and N associated with macroaggregates $(2,000$ to $250 \mu \mathrm{m})$ increased with intensification. Results indicate that grazingland intensification promoted SOC and $\mathrm{N}$ accumulation, primarily through an increase in the LF fraction.
\end{abstract}

Key words: aggregates—-grazingland—light free-soil organic matter-Spodosol

The impacts of land-use management on soil organic carbon (SOC) and nitrogen (N) dynamics have been documented extensively across different natural and managed ecosystems (Conant et al. 2001; Franzluebbers and Stuedemann 2002, 2013; Shrestha and Stahl 2008; Chan et al. 2011; Schipper et al. 2014). There is a significant body of literature suggesting that adoption of management practices that increase $\mathrm{C}$ inputs by increasing plant productivity or reducing $\mathrm{C}$ loss through less physical disturbance generally results in a net accumulation of C in soils (Abril and Bucher 1999; Conant et al. 2001, 2003; Chan et al. 2011; McSherry and Ritchie 2013). Although major gaps in our understanding with respect to the potential impacts of grazingland intensification on SOC and $\mathrm{N}$ responses, particularly in the Southern Coastal Plain region of the United States where soils are characterized by sandy texture and often offer limited protection of SOC against mineralization. In addition, a large proportion of grazinglands in this region (particularly native rangelands) is being replaced by more intensive agriculture or urban development. In this context, characterizing changes in SOC and $\mathrm{N}$ that occur in response to intensification is a key component of ascertaining the long-term sustainability of grazinglands in this ecoregion.

Research has demonstrated that increased grazingland productivity may not translate into increased SOC stocks, but rather it often affects SOC dynamics in soil size/density pools (Dubeux et al.2006a). Soil size/density fractions have been extensively used as sensitive indicators of land-use change impacts on SOC and N dynamics (Cambardella and Elliott 1992; Chan 2011; Franzluebbers and Stuedemann 2002; Wen et al. 2013; Badgery et al. 2014). Previous research has demonstrated that grazingland intensification often increases $\mathrm{C}$ associated with the more labile $\mathrm{C}$ pools such as particulate organic $\mathrm{C}$ and the light fraction (Franzluebbers and Stuedemann 2002; Conant et al. 2003; Adewopo et al. 2015). Therefore, the separation of SOC pools based on particle size and density is a useful tool to identify the changes that occur in SOC as a function of soil management (Amelung et al. 1998; Baldock and Skjemstad 2000; Romkens et al. 1999; Canellas et al. 2000). This approach has not often been applied to intensively man-

Sutie $\mathrm{Xu}$ is a PhD student at University of Florida, Range Cattle Research and Education Center, Ona, Florida. Maria L. Silveira (corresponding author) is an associate professor at University of Florida, Range Cattle Research and Education Center, Ona, Florida. Lynn E. Sollenberger is a distinguished professor in the Agronomy Department at University of Florida, Gainesville, Florida. Pedro Viegas is an associate professor in the Agronomy Department at Universidade Federal de Sergipe, Sergipe, Brazil. Julian J.J. Lacerda is an assistant professor in the Soil Science Department at Universidade Federal do Piauí, Picos, Brazil. Mariana Vieira Azenha is a postdoctoral research associate at Brazilian Agricultural Research Corporation (Embrapa) Southeast Livestock, São Carlos, Brazil. 
aged grazinglands, particularly in Spodosols of the Southern Coastal Plain. Soils in this region lack at least two critical mechanisms for sequestering SOC: (1) the physical protection of strongly developed structure and (2) physiochemical protection afforded by soil clay. In addition, the climatic conditions characterized by relatively high temperature and precipitation also limits SOC sequestration in this region. Although our previous studies demonstrated that converting native rangelands into more intensively managed grazingland ecosystems had a positive impact on SOC stocks (Adewopo et al. 2014, 2015; $\mathrm{Xu}$ et al. 2015), the effect of intensification on the processes related to SOC accumulation and stabilization in coarse-textured soils has not been fully elucidated. Therefore, the objective of this study was to evaluate longterm changes in SOC and $\mathrm{N}$ dynamics in particle size-density pools along a gradient of grazing intensification.

\section{Materials and Methods}

Experimental Site. The experimental area was located at the University of Florida, Range Cattle Research and Education Center in south-central Florida $\left(27^{\circ} 23^{\prime} \mathrm{N}\right.$, $\left.81^{\circ} 57^{\prime} \mathrm{W}\right)$. Mean annual precipitation is $\sim 1,650 \mathrm{~mm}$. Average maximum/minimum temperatures are $28^{\circ} \mathrm{C} / 17^{\circ} \mathrm{C}$. The soils were classified as Spodosols (Ona and Smyrna fine sands [sandy, siliceous, hyperthermic Typic and Aeric Alaquods, respectively]). The study was conducted on grazingland ecosystems that represent a gradient of management intensities ranging from native rangeland (lowest), silvopasture (intermediate), to sown bahiagrass (Paspalum notatum) pasture (highest). The field-replicated sites ( $\sim 6$ ha experimental units) were adjacent to each other but managed independently. Briefly, the management practices used in the native rangeland consisted of periodic burning (every three to four years) and low grazing intensity $\left(\sim 125\right.$ animal days $\left.\mathrm{ha}^{-1} \mathrm{y}^{-1}\right)$. Predominant vegetation in the native rangeland consisted of saw palmetto (Serenoa repens Bartr.) and a wide variety of grass genera including Andropogon, Panicum, Aristida, and Schizachyrium spp. Silvopastures consisted of slash pine trees (Pinus elliottii) and Pensacola bahiagrass with moderate management intensification. Nitrogen fertilization history consisted of application of $67 \mathrm{~kg} \mathrm{~N}$ $\mathrm{ha}^{-1} \mathrm{y}^{-1}$ in 1998, 1999, 2001, 2003 to 2007 , and 2010 and average stocking rates of 207 animal days $\mathrm{ha}^{-1} \mathrm{y}^{-1}$. Sown pastures represent the typical beef cattle production system in Florida and consisted of rotationally stocked pastures (stocking rate of 360 animal days $\mathrm{ha}^{-1} \mathrm{y}^{-1}$ ) receiving $67 \mathrm{~kg} \mathrm{~N} \mathrm{ha}{ }^{-1} \mathrm{y}^{-1}$ since 1991 and dolomitic limestone $\left(1 \mathrm{Mg} \mathrm{ha}^{-1}\right)$ in 2001 and 2008. More detailed information about the experimental sites is presented in Adewopo et al. (2014).

Soil Sampling. Five quadrats $(20 \mathrm{~m} \times 20 \mathrm{~m})$ spaced $\sim 75 \mathrm{~m}$ apart were established along a diagonal transect within each field-replicated experimental unit. In each quadrat, five soil core samples $(3 \mathrm{~cm}$ diameter $\times 10 \mathrm{~cm}$ height $)$ were collected from randomly selected locations in mid-summer (June and July of 2012) from the 0 to 10 and 10 to $20 \mathrm{~cm}$ depths and combined into a composited sample by depth. Soil samples were air-dried and subsequently sieved through a $2 \mathrm{~mm}$ screen.

Soil Aggregate Fractionation. Soil aggregate size separation was performed following the wet sieving method described by Six et al. (1998). Briefly, aggregates were separated by wet-sieving air-dried samples through a series of sieves. Aggregate fractions included macroaggregates (2,000 to $250 \mu \mathrm{m})$, microaggregates A (250 to $150 \mu \mathrm{m})$, microaggregates B $(150$ to $53 \mu \mathrm{m})$, and mineral-associated pool (silt + clay fraction; $<53 \mu \mathrm{m}$ ) (figure 1$)$. Each fraction was oven-dried at $55^{\circ} \mathrm{C}$ and weighed. Although information relative to SOC distribution into the various aggregate size fractions has been reported in our previous work (Silveira et al. 2014), in this current study our main focus was to evaluate the contribution of protected (occluded) versus unprotected (light-free [LF]) pools associated with the different size classes. To accomplish this goal, each aggregate class was further separated into light and heavy fractions following the procedure described by Six et al. (1998) (figure 1). Light-free material, isolated using sodium $(\mathrm{Na})$ polytungstate solution $\left(1.85 \mathrm{~g} \mathrm{~cm}^{-3}\right)$, was transferred to a $20 \mu \mathrm{m}$ nylon filter, rinsed thoroughly with deionized water, and dried at $55^{\circ} \mathrm{C}$. Similarly, the heavy fraction was rinsed with deionized water and then dispersed in $0.5 \%$ hexametaphosphate, shaken for 18 hours on a reciprocal shaker, and sieved through either a combination of $250 \mu \mathrm{m}$ and $53 \mu \mathrm{m}$ sieves (macroaggregates) or a $53 \mu \mathrm{m}$ sieve only (microaggregates). Because sand particles are expected to provide little or no protection of SOC, we anticipated that light-free C (LF-C) fraction represented a significant proportion of $\mathrm{C}$ associated with aggregate size fractions. Although our previous studies indicated that intensification promoted $\mathrm{C}$ accumulation in the particulate organic matter fraction (Adewopo et al.2015), it was unclear whether this response was due to accumulation of plant-like material recovered in this fraction versus aggregate-protected C. Therefore, in this current study we decided to further evaluate the impact of nonaggregate (LF) and aggregate-protected (occluded) fractions on $\mathrm{C}$ and $\mathrm{N}$ accumulation in soils subjected to different management intensities.

Total C and $\mathrm{N}$ concentrations in the size/ density aggregate fractions were determined by dry combustion using a Flash EA 1112 Series elemental analyzer (Thermo Fisher Scientific Inc., Waltham, Massachusetts).

Statistical Analysis. Data were analyzed using the SAS PROC MIXED procedure (SAS 2001). Soil depth and grazingland ecosystem were considered fixed effects, with replicates considered random effects. The PDIFF test of the LSMEANS procedure and single degree of freedom orthogonal contrasts were used to compare means. Treatments and their interactions were considered significant when F-test $p$-values were $<0.05$. The means reported are least squares means.

\section{Results and Discussion}

Soil Organic Carbon and Nitrogen Distribution among the Various Aggregate Size Classes. As reported in our previous work (Adewopo et al. 2014, 2015; Xu et al. 2015), total SOC and N stocks increased in response to grazingland intensification (table 1). At the 0 to $10 \mathrm{~cm}$ depth, total SOC in the native rangeland was $\sim 29 \%$ to $37 \%$ less than that in the silvopasture and sown pasture, respectively. The pattern of response was observed at the 10 to $20 \mathrm{~cm}$ depth. No differences in soil bulk density among the grazingland biomes were observed. Nitrogen concentrations across both depths were, in general, $\sim 57 \%$ to $70 \%$ smaller in the native rangeland compared with silvopasture and sown pasture system. No differences in total SOC or N concentrations between silvopasture and sown pasture were observed.

Grazingland intensification showed no effect of soil aggregation (figure 2). At the 0 to $10 \mathrm{~cm}$ depth, the greatest proportion of soil mass was recovered in the microaggregate A fraction (250 to $150 \mu \mathrm{m}$ ) (average of 382 $\mathrm{g} \mathrm{kg}^{-1}$ soil), followed by the microaggregate B (150 to $53 \mu \mathrm{m})$ and macroaggregate $(2,000$ 


\section{Figure 1}

Aggregate fractionation procedure as modified from Six et al. (2000). iPOM is intraparticulate organic matter.

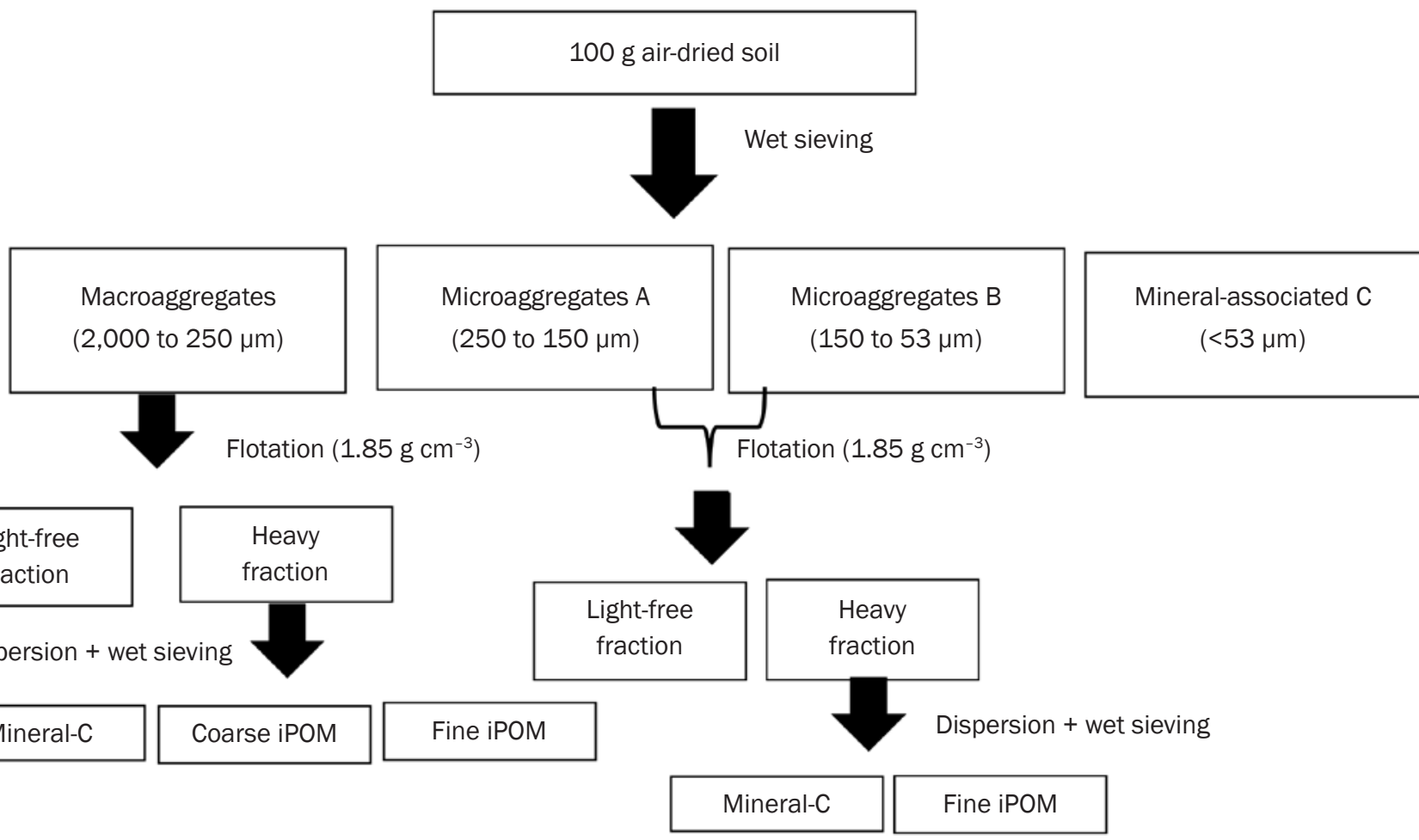

to $250 \mu \mathrm{m}$ ) fractions (average of 348 and 245 $\mathrm{g} \mathrm{kg}^{-1}$ soil, respectively). The smallest soil mass was associated with the mineral fraction $(<53$ $\mu \mathrm{m})$ (average of $22 \mathrm{~g} \mathrm{~kg}^{-1}$ soil). At the 10 to $20 \mathrm{~cm}$ depth, the greatest soil mass was recovered in microaggregate B size fraction (441 $\mathrm{g} \mathrm{kg}^{-1}$ soil), and decreased in the following order: microaggregate $\mathrm{B}$ (361 $\mathrm{g} \mathrm{kg}^{-1}$ soil) > macroaggregate (176 $\mathrm{g} \mathrm{kg}^{-1}$ soil) $>$ mineral (35 $\mathrm{g} \mathrm{kg}^{-1}$ soil). Similar results were observed in our previous study using dry sieving separation method (Silveira et al. 2014).

Although no treatment effect was observed on soil aggregation, intensity of grazingland management showed a significant effect on SOC and $\mathrm{N}$ distribution among the various aggregate size classes (table 1). In general, major differences in SOC and $\mathrm{N}$ among the three land uses were observed in the macroand microaggregate A pools. At the 0 to 10 $\mathrm{cm}$ depth, SOC associated with the macroaggregate fraction was $\sim 36 \%$ to $79 \%$ greater in silvopasture (12.8 $\mathrm{g} \mathrm{kg}^{-1}$ soil) and sown pasture (16.8 $\mathrm{g} \mathrm{kg}^{-1}$ soil), respectively, than that in the native rangeland $\left(9.4 \mathrm{~g} \mathrm{~kg}^{-1}\right.$ soil). Similarly, at the 10 to $20 \mathrm{~cm}$ depth, SOC associated with macroaggregates increased from $2.7 \mathrm{~g} \mathrm{~kg}^{-1}$ soil in the native rangeland to $7.8 \mathrm{~g} \mathrm{~kg}^{-1}$ soil in the sown pasture.
Nitrogen accumulation in response to grazingland intensification occurred mainly in the macroaggregate pool (table 1). Nitrogen associated with macroaggregates increased two- to four-fold in response to the conversion of native rangelands into sown pastures. No effect of grazingland intensification was observed in the finer $(<250 \mu \mathrm{m})$ aggregate fractions.

The relative distribution of SOC associated with each aggregate size fraction (percentage of total C in the bulk soil) was not affected by management intensification. On average, at the 0 to $10 \mathrm{~cm}$ depth, $\sim 50 \%$ of total soil $\mathrm{C}$ was present in the macroaggregate fraction, while $26 \%, 15 \%$, and $8 \%$ of total $\mathrm{C}$ was associated with the microaggregate $\mathrm{A}$, microaggregate $\mathrm{B}$, and mineral-associated fractions, respectively.

Light-Free Carbon. Grazingland intensification increased SOC and $\mathrm{N}$ associated with the LF fraction (table 2). The LF fraction associated with macro- and microaggregates was generally enriched in $\mathrm{C}$ and $\mathrm{N}$ in the sown pastures compared with silvopasture and native rangelands. Largest differences were observed in the macroaggregate pool. At the 0 to $10 \mathrm{~cm}$ depth, LF-C concentrations associated with the macroaggregates were two- to eight-fold greater in the sown pasture (62 $\mathrm{g} \mathrm{LF}^{-\mathrm{C} \mathrm{kg}} \mathrm{kg}^{-1}$ aggregate) as compared with the silvopasture (27 $\mathrm{g} \mathrm{LF}-\mathrm{C} \mathrm{kg}^{-1}$ aggregate) and native rangeland (7.8 $\mathrm{g} \mathrm{LF}_{-} \mathrm{C} \mathrm{kg}^{-1}$ aggregate), respectively. A similar response was observed for N. Overall, LF-C increased in the following order: native rangeland < silvopasture < sown pasture. Light-free C in both macroaggregate and microaggregate fractions decreased with soil depth.

The mass of $\mathrm{C}$ and $\mathrm{N}$ associated with LF (g C or $\mathrm{N} \mathrm{kg}^{-1}$ soil) followed a similar pattern of response (table 2). Sown pasture exhibited the greatest $\mathrm{LF}-\mathrm{C}$ (32 $\mathrm{g} \mathrm{LF}-\mathrm{C} \mathrm{kg}^{-1}$ soil) and LF-N (5.9 $\mathrm{g} \mathrm{LF}-\mathrm{N} \mathrm{kg}^{-1}$ soil) compared with the silvopasture (20 $\mathrm{g} \mathrm{LF}_{-} \mathrm{C} \mathrm{kg}^{-1}$ soil and $3 \mathrm{~g}$ LF-N kg ${ }^{-1}$ soil) and native rangeland (15.8 $\mathrm{g}$ LF-C kg-1 soil and $1 \mathrm{~g}$ LF-N kg-1 soil). At 0 to $10 \mathrm{~cm}, \mathrm{LF}-\mathrm{C}$ represented $82 \%$ of total SOC present in the bulk soil, while the proportion of LF-C relative to total SOC was $50 \%$ in the silvopasture and $67 \%$ in the native rangeland (table 3 ). Conversely, at the same depth, the proportion of $\mathrm{C}$ recovered in the mineral fraction was greatest in silvopasture, least in sown pasture, and intermediate in native rangeland. At the 10 to 20 $\mathrm{cm}$ depth, LF-C accounted for 39\%, 43\%, and $27 \%$ of total SOC in the sown pasture, 


\section{Figure 2}

Aggregate mass distribution. Macroaggregate $=2,000$ to $250 \mu \mathrm{m}$, microaggregates $\mathrm{A}=250$ to $150 \mu \mathrm{m}$, microaggregates $B=150$ to $53 \mu \mathrm{m}$, and mineral (silt + clay) fraction $=\langle 53 \mu \mathrm{m}$. Data represent the average across all treatments. Bars represent one standard error. Means with the same letter within soil depth are not different using the LSMEANS procedure $(p>0.05)$.

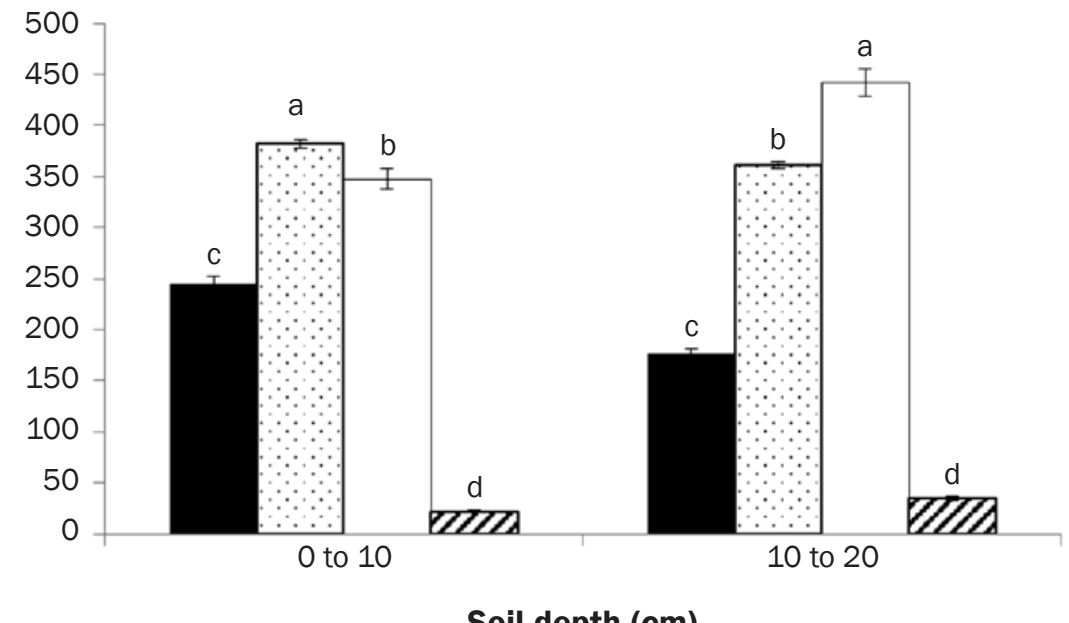

Soil depth (cm)
Legend

- Macroaggregate
Microaggregate A
Microaggregate B
Mineral silvopasture, and native rangeland, respectively. Similarly, a much greater proportion of $\mathrm{N}$ was associated with the LF fraction in the sown pasture ( $85 \%$ of total $\mathrm{N}$ ) compared with native rangeland $(60 \%$ of total $\mathrm{N})$ and silvopasture (53\% of total $\mathrm{N}$ ) (table 3 ).

Intraparticulate Organic Matter. Carbon associated with microaggregate intraparticulate organic matter (iPOM) $(0$ to $10 \mathrm{~cm}$ depth) was affected by grazingland intensification, but no differences were observed in the macroaggregates' iPOM fractions (figure 3). At the 0 to $10 \mathrm{~cm}$ soil depth, the greatest microaggregate iPOM C was associated with sown pasture (1.3 $\mathrm{g} \mathrm{kg}^{-1}$ soil), followed by silvopasture $\left(1 \mathrm{~g} \mathrm{~kg}^{-1}\right.$ soil $)$ and native rangeland $\left(0.7 \mathrm{~g} \mathrm{~kg}^{-1}\right.$ soil). No treatment effect was observed in the 10 to $20 \mathrm{~cm}$ depth. Similarly, the relative proportion of $\mathrm{C}$ associated with fine iPOM decreased from 10\% of total SOC in the native rangeland to $6 \%$ of total SOC in the sown pasture. Because of the relatively low concentrations (below the detection limit of $0.01 \%$ ), the amount of $\mathrm{N}$ associated with the $\mathrm{PPOM}$ fractions was considered negligible.

Grazingland Intensification Impacts on Soil Organic Carbon and Nitrogen Dynamics. Grazingland management practices intended to increase forage or animal production such as the introduction of more productive plant species, fertilization, and grazing intensity and frequency can strongly influence the amounts and characteristics of SOC and N (Conant et al. 2001; Schuman et al. 2002; Wright et al. 2004; Derner and Schuman 2007; Follett and Reed 2010). Results reported in the current study are in agreement with our previous work that demonstrated that conversion of native rangeland into more intensively managed systems can result in increased SOC and $\mathrm{N}$ stocks (Adewopo et al. 2014; Xu et al. 2015). These data are also in agreement with Conant et al. (2001) who reported similar SOC responses as result of the adoption of improved grazingland management practices. Soil organic C accumulation in sown pasture occurred primarily due to the replacement of C3 native species with more productive C4 grasses, and adoption of grazing and fertilizer management practices that resulted in greater ecosystem productivity (Adewopo et al. 2014). Similar responses have been reported previously in a variety of grazingland ecosystem types (Fisher et al. 1994; Conant et al. 2001; Wright et al. 2004; McSherry and Ritchie 2013). However, it should be noted that our findings may be most applicable to ecological sites with similar conditions due to the constraints associated with the nondispersal of replicates in space under the studied long-term ecological units.
Light-Free and Mineral-Associated Carbon and Nitrogen. Despite the positive impact of grazingland intensification on SOC and N, our data suggest that SOC and $\mathrm{N}$ accumulation following conversion of native rangelands into sown pastures occurred primarily in more labile forms. For instance, our data show that LF-C increased by as much as 2.7 times with increased management intensity. The increases in labile $\mathrm{C}$ forms in response to management intensification observed in this current study are in agreement with previous studies in similar soil type and climate conditions (Dubeux et al. 2006a). Those authors found that litter deposition and litter quality increased as grazingland management intensified (Dubeux et al. 2006b, 2006c), and this was associated with an increase in C accumulation in the LF fraction (Dubeux et al. 2006a). Changes in the LF fraction have been highly correlated with residue input (Gregorich and Jazen 1996; Six et al. 1998), and LF has been widely recognized as a sensitive indicator of the effects of land use management (Janzen et al. 1992). Our previous data on litter deposition and composition (Xu et al. 2015) are consistent with the increases in LF-C observed in the sown pasture in this current study. Franzluebbers and Stuedemann (2002) suggested that cattle trampling can also promote plant residue incorporation and, therefore, affect labile SOC pools, particularly at the surface soil depth. Therefore, in addition to the greater SOC inputs via above- and belowground pools, the greater stocking rate associated with the sown pasture may also have favored accumulation of LF-C and $\mathrm{N}$ at the 0 to $10 \mathrm{~cm}$ depth.

Although no treatment effect on SOC mass (g C kg-1 soil) was observed in the mineral fraction, our results demonstrated that a greater proportion of SOC was associated with the mineral fraction in the silvopasture (0 to $10 \mathrm{~cm}$ depth) compared with the other ecosystems. However, no differences in mineral $\mathrm{C}$ between silvopasture and sown pastures were observed at the 10 to $20 \mathrm{~cm}$ depth. This response contradicts Haile et al. (2010) who observed a greater proportion of SOC associated with mineral fraction in silvopastures versus sown pastures in Florida. These latter authors suggested C associated with the mineral fraction was primarily derived from slash pine trees, and the contribution of the trees increased as the soil depth increased. 
Table 1

Soil organic carbon (SOC) and nitrogen (N) distribution among the various aggregate size classes at two soil depths as affected by grazingland management.

\begin{tabular}{|c|c|c|c|c|c|c|c|c|c|c|}
\hline $\begin{array}{l}\text { Grazing land } \\
\text { ecosystem }\end{array}$ & $\begin{array}{l}\text { Total SOC } \\
\text { (g C kg-1 soil) }\end{array}$ & $\begin{array}{l}\text { Macroaggregate } \\
\text { (g C kg-1 soil) }\end{array}$ & $\begin{array}{l}\text { Microaggregate } \\
\mathrm{A} \text { (g C kg-1 soil) }\end{array}$ & $\begin{array}{l}\text { Microaggregate } \\
\text { B (g C kg-1 soil) }\end{array}$ & $\begin{array}{l}\text { Mineral } \\
\left(\mathrm{g} C \mathrm{~kg}^{-1} \text { soil) }\right.\end{array}$ & $\begin{array}{l}\text { Total N } \\
\text { (g N kg-1 soil) }\end{array}$ & $\begin{array}{l}\text { Macroaggregate } \\
\text { (g N kg-1 soil) }\end{array}$ & $\begin{array}{l}\text { Microaggregate } \\
\text { A (g N kg-1 soil) }\end{array}$ & $\begin{array}{l}\text { Microaggregate } \\
\text { B (g N kg-1 soil) }\end{array}$ & $\begin{array}{l}\text { Mineral } \\
\text { (g N kg-1 soil) }\end{array}$ \\
\hline \multicolumn{11}{|l|}{0 to $10 \mathrm{~cm}$} \\
\hline Native rangeland & $19.2 b *$ & $9.4 c$ & $5.4 b$ & $2.7 a$ & $1.7 a$ & $1.0 b$ & $0.5 b$ & $0.4 a$ & $0.03 a$ & $0.1 \mathrm{a}$ \\
\hline Silvopasture & $27.2 a$ & $12.8 b$ & $6.1 \mathrm{ab}$ & $5.4 a$ & $2.9 a$ & $1.7 a$ & $0.7 a$ & $0.4 a$ & $0.4 a$ & $0.2 a$ \\
\hline Sown pasture & $30.2 a$ & $16.8 \mathrm{a}$ & $8.5 a$ & 3.3a & $1.7 a$ & $2.0 a$ & $1.1 \mathrm{a}$ & $0.6 a$ & $0.2 \mathrm{a}$ & $0.1 \mathrm{a}$ \\
\hline SE & 4.3 & 1.4 & 0.7 & 0.7 & 0.5 & 0.2 & 0.1 & 0.05 & 0.08 & 0.05 \\
\hline \multicolumn{11}{|l|}{10 to $20 \mathrm{~cm}$} \\
\hline Native rangeland & $10.8 b$ & $2.7 b$ & $2.3 b$ & $2.3 b$ & $3.5 a$ & $0.3 b$ & $0.1 b$ & $0.01 a$ & $0.01 a$ & $0.2 \mathrm{a}$ \\
\hline Silvopasture & $15.4 a$ & $4.2 \mathrm{a}$ & $2.8 b$ & $5.6 a$ & $2.8 \mathrm{a}$ & $0.7 a$ & $0.2 a$ & $0.01 a$ & $0.4 a$ & $0.1 a$ \\
\hline Sown pasture & $20.1 \mathrm{a}$ & $7.8 \mathrm{a}$ & $6.0 a$ & $4.0 \mathrm{ab}$ & $2.3 a$ & $1.0 \mathrm{a}$ & $0.4 a$ & $0.4 a$ & $0.1 a$ & $0.1 a$ \\
\hline SE & 3.0 & 1.2 & 0.8 & 0.6 & 0.6 & 0.1 & 0.06 & 0.08 & 0.08 & 0.05 \\
\hline
\end{tabular}

Note: SE = standard error.

* Means $(n=2)$ within a soil depth followed by the same letter are not different using the LSMEANS procedure $(p>0.05)$.

Table 2

Grazingland intensification effects on light-free (LF) soil organic carbon (C) and nitrogen (N) pools at two soil depths.

\begin{tabular}{|c|c|c|c|c|c|c|}
\hline $\begin{array}{l}\text { Grazingland } \\
\text { ecosystem }\end{array}$ & $\begin{array}{l}\text { Macroaggregate } \\
\text { LF-C (g C kg-1 } \\
\text { aggregate) }\end{array}$ & $\begin{array}{l}\text { Microaggregate } \\
\text { LF-C (g C kg }{ }^{-1} \\
\text { aggregate) }\end{array}$ & $\begin{array}{l}\text { Sum LF-C } \\
\text { (g C kg-1 aggregate) }\end{array}$ & $\begin{array}{l}\text { Macroaggregate } \\
\text { LF-N (g N kg }{ }^{-1} \\
\text { aggregate) }\end{array}$ & $\begin{array}{l}\text { Microaggregate } \\
\text { LF-N (g N kg-1 } \\
\text { aggregate) }\end{array}$ & $\begin{array}{l}\text { Sum LF-N } \\
\text { (g N kg }{ }^{-1} \text { aggregate) }\end{array}$ \\
\hline \multicolumn{7}{|l|}{0 to $10 \mathrm{~cm}$} \\
\hline Native rangeland & $7.8 \mathrm{c} *(7.4) \dagger$ & $8.1 b(5.5)$ & 16.0c (12.9) & $0.3 c(0.3)$ & $0.4 b(0.3)$ & $0.7 c(0.6)$ \\
\hline Silvopasture & $27.1 \mathrm{~b}(5.1)$ & 11.1a (8.6) & $38.2 b(13.7)$ & $1.5 b(0.3)$ & $0.7 \mathrm{ab}(0.6)$ & $2.2 b(0.9)$ \\
\hline Sown pasture & 62.3a (14.8) & $13.4 a(9.9)$ & $75.7 a(24.7)$ & $4.1 \mathrm{a}(1.0)$ & $0.9 a(0.7)$ & $5.0 \mathrm{a}(1.7)$ \\
\hline \multicolumn{7}{|l|}{10 to $20 \mathrm{~cm}$} \\
\hline Native rangeland & $7.9 b(1.1)$ & $2.1 b(1.8)$ & $10.0 \mathrm{~b}(2.9)$ & $0.2 b(0.03)$ & $0.1 b(0.09)$ & $0.3 b(0.1)$ \\
\hline Silvopasture & 10.5a (1.8) & $6.1 \mathrm{a}(4.8)$ & 16.6a (6.6) & $0.5 a(0.08)$ & $0.3 a(0.3)$ & $0.8 \mathrm{a}(0.4)$ \\
\hline Sown pasture & $11.5 a(2.6)$ & $6.8 a(5.2)$ & $18.2 \mathrm{a}(7.8)$ & $0.6 a(0.1)$ & $0.4 a(0.4)$ & $0.9 a(0.5)$ \\
\hline
\end{tabular}

* Means within a soil depth followed by the same letter are not different using the LSMEANS procedure $(p>0.05)$.

†Values in parentheses represent the mass of LF-C or LF-N per unit of soil (g LF-C or LF-N kg-1 of soil).

Table 3

Soil organic carbon $(\mathrm{C})$ and nitrogen $(\mathrm{N})$ relative distribution among the various particle size/density pools at two soil depths.

\begin{tabular}{|c|c|c|c|c|c|c|}
\hline $\begin{array}{l}\text { Grazingland } \\
\text { ecosystem }\end{array}$ & $\begin{array}{l}\text { Light-free C } \\
\text { (\% total C) }\end{array}$ & $\begin{array}{l}\text { Coarse iPOM } \\
\text { (\% total C) }\end{array}$ & $\begin{array}{l}\text { Fine iPOM } \\
\text { (\% total } \mathrm{C})\end{array}$ & $\begin{array}{l}\text { Mineral- } \\
\text { associated C } \\
\text { (\% total C) }\end{array}$ & $\begin{array}{l}\text { Light-free } \mathbf{N} \\
\text { (\% total } N)\end{array}$ & $\begin{array}{l}\text { Mineral- } \\
\text { associated } \mathbf{N} \\
(\% \text { total } \mathrm{N})\end{array}$ \\
\hline \multicolumn{7}{|l|}{0 to $10 \mathrm{~cm}$} \\
\hline Native rangeland & $67 b *$ & $3 a$ & $10 a$ & $20 b$ & $60 b$ & $40 a$ \\
\hline Silvopasture & $50 c$ & $2 a$ & $8 a$ & $40 a$ & $53 b$ & $47 a$ \\
\hline Sown pasture & $82 a$ & $\mathrm{Oa}$ & $6 b$ & $12 c$ & $85 a$ & $15 b$ \\
\hline \multicolumn{7}{|l|}{10 to $20 \mathrm{~cm}$} \\
\hline Native rangeland & $27 b$ & $1 a$ & $8 a$ & $64 a$ & $40 b$ & $60 a$ \\
\hline Silvopasture & $43 a$ & $\mathrm{Oa}$ & $6 a$ & $51 b$ & $57 a$ & $43 b$ \\
\hline Sown pasture & $39 a$ & $1 a$ & $7 a$ & $53 b$ & $50 a$ & $50 b$ \\
\hline
\end{tabular}

Note: $\mathrm{iPOM}=$ intraparticulate organic matter.

* Means within a soil depth followed by the same letter are not different using the LSMEANS procedure ( $p>0.05)$. 


\section{Figure 3}

Grazingland intensification effect on intraparticulate organic matter (iPOM) for two soil depths ([a] o to $10 \mathrm{~cm}$ and [b] 10 to $20 \mathrm{~cm})$. CiPOM and FiPOM = coarse $(2,000$ to $250 \mu \mathrm{m})$ and fine $(250$ to $53 \mu \mathrm{m}$ ) intraparticulate organic matter in macroaggregates, respectively. Microaggregate iPOM = fine ( 250 to $53 \mu \mathrm{m}$ ) intraparticulate organic matter in microaggregates. Bars represent one standard error. Means with the same letter within fraction are not different using the LSMEANS procedure $(p>0.05)$.

(a)
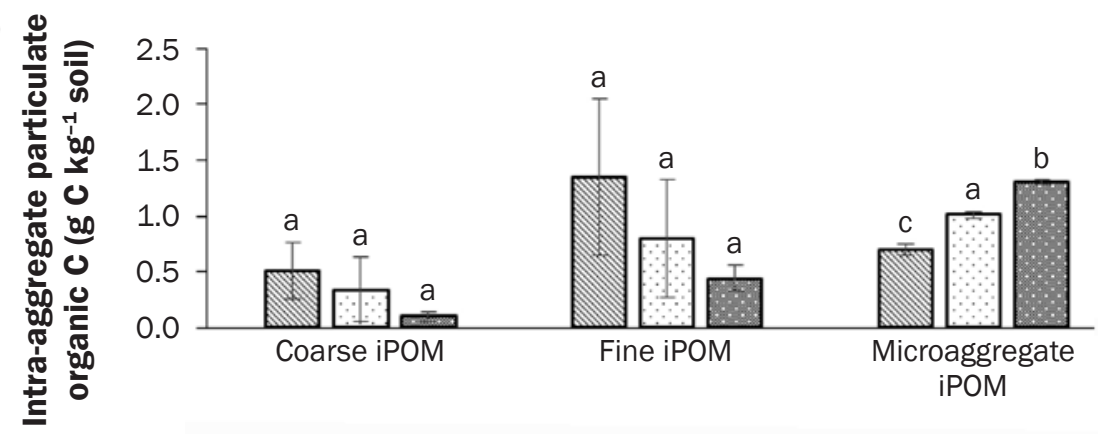

(b)
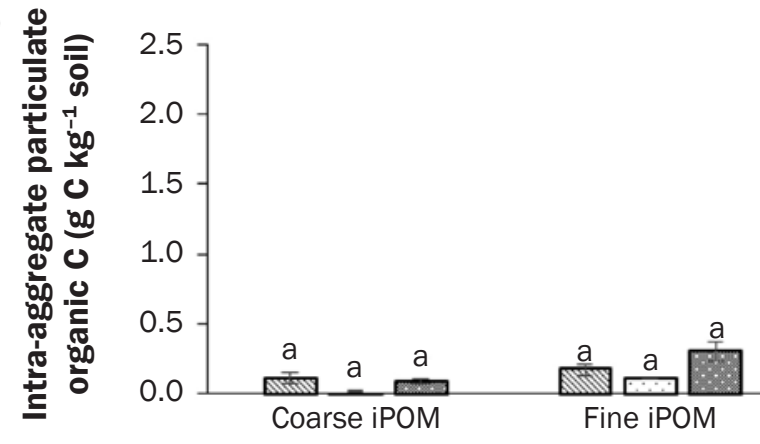

Legend

N Native rangeland

$\square$ Silvopasture

Sown pasture

Carbon concentration ( $\mathrm{g} \mathrm{C} \mathrm{kg}^{-1}$ aggregate) associated with the mineral pool increased with grazingland intensification. Enrichment of $\mathrm{C}$ in this fraction has been reported in various studies under similar environmental and soil type conditions (Dubeux et al. 2006a; Silveira et al. 2013, 2014). Silveira et al. (2013) reported that $\mathrm{C}$ concentration in $<53 \mu \mathrm{m}$ fraction can change in response to ecosystem management because the mineral fraction in this soil was dominated by quartz, and, therefore, had low ability to protect SOC against mineralization. Similar to our findings, Adewopo et al. (2015) also reported that conversion of native rangelands into silvopasture systems increased the mineral-associated C (5.7 versus $10 \mathrm{~g} \mathrm{C} \mathrm{kg}^{-1}$ for native rangelands and silvopasture, respectively).

Soil Organic Carbon and Nitrogen Distribution among Various Aggregate Classes. Macroaggregates (2,000 to $250 \mu \mathrm{m})$ accumulated the greatest amounts of SOC and $\mathrm{N}$ compared with the other soil aggregate size classes. Averaged across the three ecosystems, macroaggregates accounted for $\sim 50 \%$ of total SOC and $\mathrm{N}$ at the 0 to 10 $\mathrm{cm}$ depth. Similar responses were reported by Sarkhot et al. (2007) who indicated that $\sim 50 \%$ of the total SOC was associated with macroaggregate fraction in a Florida Spodosol. These authors concluded that this fraction was more sensitive to management intensification compared with the fine aggregate classes. Corroborating our results, Conant et al. (2004) observed that the majority of the total SOC was associated with the macroaggregate fraction in pasture and forest ecosystems in the southeastern United States. Tonucci et al. (2011) also found that macroaggregates accounted for the greatest proportion of SOC in silvopasture systems. In this current study, SOC associated with macroaggregates in sown pasture and silvopasture was $\sim 1.4$ to 1.8 times greater than that in the native rangeland. These results are in agreement with the general assumption that $\mathrm{C}$ associated with macroaggregates is more labile (Tiessen and Stewart 1983) than that in the finer particle size pools, and, therefore, more sensitive to ecosystem management (Elliott and Coleman 1988; Six et al. 2004). Similarly, N accumulation due to the conversion of native rangelands into silvopasture or sown pasture occurred primarily in the macroaggregate fraction.

Despite the positive impacts of grazingland intensification on SOC and $\mathrm{N}$ associated with macroaggregates, we found that grazingland intensification had no effect on soil aggregation; therefore, SOC and $\mathrm{N}$ accumulation observed in the macroaggregate fraction occurred primarily due to increases in the LF pool, particularly at the surface soil depth. Although our previous studies demonstrated that $\mathrm{C}$ accumulation in the aggregate size pools was generally promoted as grazingland management increased (Silveira et al. 2014), it was unclear whether this response was due to increases in protected (occluded C) or nonprotected LF. Results from this current study indicated that although $\mathrm{C}$ concentration associated with macroaggregates increased from $32 \mathrm{~g} \mathrm{C}$ $\mathrm{kg}^{-1}$ aggregate in the native rangeland to 67 and $70 \mathrm{~g} \mathrm{C} \mathrm{kg}^{-1}$ aggregate in the silvopasture and sown pasture, respectively, LF-C accounted for the majority of the $\mathrm{C}$ present in the macroaggregate size class. For instance, at the 0 to $10 \mathrm{~cm}$ depth, LF-C represented $\sim 87 \%$ of the total $\mathrm{C}$ present in the macroaggregate in the sown pasture, while in the native rangeland this proportion was $79 \%$. At the 10 to $20 \mathrm{~cm}$ depth, LF-C, on average, accounted for $33 \%$ to $41 \%$ of total SOC present in the macroaggregates. The hypothesis that SOC accumulation in response to conversion of native rangelands into more intensively managed grazingland ecosystems is primarily due to enrichment in LF pools is further supported by our iPOM data. While our results demonstrated that SOC associated with microaggregate iPOM increased with grazingland intensification, a greater proportion of LF-C was associated with silvopasture and sown pasture compared with native rangelands. Conversely, a much greater proportion of microaggregate $\mathrm{C}$ was associated with the mineral pool in native rangeland, suggesting the increases in 
SOC associated with increased intensification was caused by the increases in LF-C in sown pasture and silvopasture.

\section{Summary and Conclusions}

Long-term grazingland intensification (herein defined as change in vegetation composition, grazing management, and $\mathrm{N}$ fertilizer inputs) promoted SOC and $\mathrm{N}$ accumulation in subtropical ecosystems. Data also demonstrated that SOC and $\mathrm{N}$ accumulation in response to the conversion of native rangelands into silvopasture and sown pasture was primarily attributed to increases in SOC and $\mathrm{N}$ associated with the LF pool. Although our results indicated that grazingland intensification affected SOC and $\mathrm{N}$ distribution among the various aggregate size classes, unprotected LF comprised a large proportion of SOC and $\mathrm{N}$ associated with macro- and microaggregates; therefore, the observed increases in SOC and $\mathrm{N}$ may simply reflect accumulation of plant-like material recovered in the various aggregate size classes rather than a mechanism of physical or chemical protection in response to grazingland intensification.

\section{Acknowledgements}

This study was partially supported by the Southern Region USDA Program on Sustainable Agriculture Research and Education (SARE).

\section{References}

Abril, A., and E.H. Bucher. 1999. The effects of overgrazing on soil microbial community and fertility in the Chaco dry savannas of Argentina. Applied Soil Ecology 12(2):159-167.

Adewopo, J.B., M.L. Silveira, S. Xu, S. Gerber, L.E. Sollenberger, and T.A. Martin. 2014. Management intensification impacts on soil and ecosystem carbon stocks in subtropical grasslands. Soil Science Society of America Journal 78(3):977-986.

Adewopo, J.B., M.L. Silveira, S. Xu, S. Gerber, L.E. Sollenberger, and T.A. Martin. 2015. Management intensification impacts on particle-size soil carbon fractions in subtropical grasslands: Evidence from ${ }^{13} \mathrm{C}$ natural abundance. Soil Science Society of America Journal 79:1198-1205.

Amelung, W., W. Zech, X. Zhang, R.F. Follett, H. Tiessen, E. Knox, and K.W. Flach. 1998. Carbon, nitrogen, and sulfur pools in particle-size fractions as influenced by climate. Soil Science Society of America Journal 62:172-181.

Badgery, W.B., A.T. Simmons, B.W. Murphy, A. Rawson, K.O. Andersson, and V.E. Lonergan. 2014. The influence of land use and management on soil carbon levels for crop-pasture systems in Central New South Wales, Australia. Agriculture, Ecosystems and Environment 196:147-157.

Baldock, J.A., and J.O. Skjemstad. 2000. Role of soil matrix and minerals in protecting natural organic materials against biological attack. Organic Geochemistry 31:697-710.

Cambardella, C.A., and E.T. Elliott. 1992. Particulate soil organic-matter changes across a grassland cultivation sequence. Soil Science Society of America Journal 56(3):777-783.

Canellas, L.P., P.G. Berner, S.G. da Silva, M.B.E. Silva, and G.D. Santos. 2000. Organic matter fractions in a toposequence of six soils in the state of Rio de Janeiro, Brazil. Pesquisa Agropecuaria Brasileira 35:133-143.

Chan, K.Y., M.K. Conyers, G.D. Li, K.R. Helyar, G. Poile, A. Oates, and I.M. Barchia. 2011. Soil carbon dynamics under different cropping and pasture management in temperate Australia: Results of three long-term experiments. Soil Research 49(4):320-328.

Conant, R.T., K. Paustian, and E.T. Elliott. 2001. Grassland management and conversion into grassland: Effects on soil carbon. Ecological Applications 11(2):343-355.

Conant, R.T., J. Six, and K. Paustian. 2003. Land use effects on soil carbon fractions in the southeastern United States. I. Management-intensive versus extensive grazing. Biology and Fertility of Soils 38(6):386-392.

Conant, R.T., J. Six, and K. Paustian. 2004. Land use effects on soil carbon fractions in the southeastern United States. II. Changes in soil carbon fractions along a forest to pasture chronosequence. Biology and Fertility of Soils 40(3):194-200.

Derner, J.D., and G.E. Schuman. 2007. Carbon sequestration and rangelands: A synthesis of land management and precipitation effects. Journal of Soil and Water Conservation 62(2):77-85.

Dubeux, J.C.B., L.E. Sollenberger, N.B. Comerford, J.M. Scholberg, A.C. Ruggieri, J.M.B.Vendramini, and K.M. Portier. 2006a. Management intensity affects density fractions of soil organic matter from grazed bahiagrass swards. Soil Biology and Biochemistry 38(9):2705-2711.

Dubeux, J.C.B., L.E. Sollenberger, S.M. Interrante, J.M.B. Vendramini, and R.L. Stewart. 2006b. Litter decomposition and mineralization in bahiagrass pastures managed at different intensities. Crop Science 46(3):1305-1310.

Dubeux, J.C.B., L.E. Sollenberger, J.M.B. Vendramini, R.L. Stewart, and S.M. Interrante. 2006c. Litter mass, deposition rate, and chemical composition in bahiagrass pastures managed at different intensities. Crop Science 46(3):1299-1304.

Elliott, E.T., and D.C. Coleman. 1988. Let the soil work for us. Ecological Bulletins 39:23-32.

Fisher, M.J., I.M. Rao, M.A. Ayarza, C.E. Lascano, J.I. Sanz, R.J. Thomas, and R.R. Vera. 1994. Carbon storage by introduced deep-rooted grasses in the South American savannas. Nature 371:236-238.
Follett, R.F., and D.A. Reed. 2010. Soil carbon sequestration in grazing lands: Societal benefits and policy implications. Rangeland Ecology and Management 63(1):4-15.

Franzluebbers, A.J., J. Sawchik, and M.A. Taboada. 2014. Agronomic and environmental impacts of pasturecrop rotations in temperate North and South America. Agriculture, Ecosystems, and Environment 190:18-26.

Franzluebbers, A.J., and J.A. Stuedemann. 2002. Particulate and non-particulate fractions of soil organic carbon under pastures in the Southern Piedmont USA. Environmental Pollution 116:S53-S62.

Franzluebbers, A.J., and J.A. Stuedemann. 2013. Soil-profile distribution of organic $\mathrm{C}$ and $\mathrm{N}$ after 6 years of tillage and grazing management. European Journal of Soil Science 64(5):558-566

Gregorich, E.G., and H.H. Janzen. 1996. Storage of soil carbon in the light fraction and macro organic matter. In Advances in Soil Science-Structure and Organic Matter Storage in Agricultural Soils, ed. M.R. Carter and B.A. Stewart, 167-190. Boca Raton, FL: CRC Press.

Haile, S.G., V.D. Nair, and P.K. Nair. 2010. Contribution of trees to carbon storage in soils of silvopastoral systems in Florida, USA. Global Change Biology 16(1):427-438.

Janzen, H.H., C.A. Campbell, S.A. Brandt, G.P. Lafond, and L. Townley-Smith. 1992. Light-fraction organic matter in soils from long-term crop rotations. Soil Science Society of America Journal 56(6):1799-1806.

McSherry, M.E., and M.E. Ritchie. 2013. Effects of grazing on grassland soil carbon: A global review. Global Change Biology 19(5):1347-1357.

Oldeman, L.R. 1994. The global extent of land degradation. In Land Resilience and Sustainable Land Use, ed. D.J. Greenland and I. Szabolcs, 99-118. Wallingford, UK: $\mathrm{CAB}$ International.

Reid, R.S., P.K. Thornton, G.J. McCrabb, R.L. Kruska, F Atieno, and P.G. Jones. 2004. Is it possible to mitigate greenhouse gas emissions in pastoral ecosystems of the tropics? Environment, Development and Sustainability 6:91-109.

Romkens, P.F.A.M., J. van der Plicht, and J. Hassink. 1999. Soil organic matter dynamics after the conversion of arable land to pasture. Biology and Fertility of Soils 28:277-284

Sarkhot, D.V., N.B. Comerford, E.J. Jokela, and J.B. Reeves III. 2007. Effects of forest management intensity on carbon and nitrogen content in different soil size fractions of a North Florida Spodosol. Plant and Soil 294(1-2):291-303.

SAS Institute. 2001. SAS Release 82. Cary, NC: SAS Institute.

Schipper, L.A., R.L. Parfitt, S. Fraser, R.A. Littler, W.T. Baisden, and C. Ross. 2014. Soil order and grazing management effects on changes in soil $\mathrm{C}$ and $\mathrm{N}$ in New Zealand pastures. Agriculture, Ecosystems and Environment 184:67-75. 
Schuman, G.E., H.H. Janzen, and J.E. Herrick. 2002. Soil carbon dynamics and potential carbon sequestration by rangelands. Environmental Pollution 116(3):391-396.

Shrestha, G., and P.D. Stahl. 2008. Carbon accumulation and storage in semi-arid sagebrush steppe: Effects of long-term grazing exclusion. Agriculture, Ecosystems and Environment 125(1):173-181.

Silveira, M.L., K. Liu, L.E. Sollenberger, R.F. Follett, and J.M.B. Vendramini. 2013. Short-term effects of grazing intensity and nitrogen fertilization on soil organic carbon pools under perennial grass pastures in the southeastern USA. Soil Biology and Biochemistry 58:42-49.

Silveira, M.L., S. Xu, J. Adewopo, A.J. Franzluebbers, and G. Buonadio. 2014. Grazing land intensification effects on soil C dynamics in aggregate size fractions of a Spodosol. Geoderma 230:185-193.

Six, J., H. Bossuyt, S. Degryze, and K. Denef. 2004. A history of research on the link between (micro) aggregates, soil biota, and soil organic matter dynamics. Soil and Tillage Research 79(1):7-31.

Six, J., E.T. Elliott, K. Paustian, and J.W. Doran. 1998. Aggregation and soil organic matter accumulation in cultivated and native grassland soils. Soil Science Society of America Journal 62(5):1367-1377.

Tiessen, H., and J.W.B. Stewart. 1983. Particle-size fractions and their use in studies of soil organic matter: II. Cultivation effects on organic matter composition in size fractions. Soil Science Society of America Journal 47(3):509-514.

Tonucci, R.G., P.K. Nair, V.D. Nair, R. Garcia, and F.S. Bernardino. 2011. Soil carbon storage in silvopasture and related land-use systems in the Brazilian Cerrado. Journal of Environmental Quality 40(3):833-841.

Xu, S., M.L. Silveira, K.S. Inglett, L.E. Sollenberger, and S. Gerber. 2015. Effect of land-use conversion on ecosystem $\mathrm{C}$ stock and distribution in subtropical grazing lands. Plant and Soil 399(1-2):233-245.

Wen, H., D. Niu, H. Fu, and J. Kang. 2013. Experimental investigation on soil carbon, nitrogen, and their components under grazing and livestock exclusion in steppe and desert steppe grasslands, Northwestern China. Environmental Earth Sciences 70(7):3131-3141.

Wright, A.L., F.M. Hons, F.M. Rouquette, Jr. 2004. Longterm management impacts on soil carbon and nitrogen dynamics of grazed bermudagrass pastures. Soil Biology and Biochemistry 36(11):1809-1816. 